\title{
Perencanaan Lanskap dan Strategi Pengembangan Potensi Daya Tarik Ekowisata Batu Rongring Taman Nasional Gunung Leuser
}

\author{
Ovie Farizal $^{1 *}$, Hamdani Harahap ${ }^{2}$, Marifatin Zahra ${ }^{3}$ \\ ${ }^{1}$ Program Magister Program Studi Pengelolaan Sumberdaya Alam dan Lingkungan, USU \\ ${ }^{2}$ Fakultas Ilmu Sosial dan Ilmu Politik, Universitas Sumatera Utara \\ ${ }^{3}$ Fakultas Kehutanan, Universitas Sumatera Utara \\ *Koresponden email: oph13.f@gmail.com
}

Diterima: 27 Februari 2020

Disetujui: 11 Maret 2020

\begin{abstract}
Batu Rongring Ecotourism is in the buffer zone of National Park of Gunung Leuser (TNGL). The uniqueness of ecosystems, customs, and flora of the flora makes Batu Rongring Ecotourism interesting to visit. Batu Rongring Ecotourism Planning and Development must be in accordance with the characteristics and potential of the Natural Attraction Attraction (ODTWA) in Batu Rongring. This study aims to analyze landscape planning in developing Batu Rongring ecotourism as a buffer for TNGL. ODTWA potential analysis for the Rongring Stone Development Strategy uses internal factor analysis (IFAS), external factors (EFAS) and SWOT Analysis. Landscape planning is done by involving stakeholders in the Forum Group Disscusion (FGD). The results of the assessment in the development of Batu Rongring Ecotourism is known the value of IFAS $=2.71$ which makes the strategy in the development of Rongring Stone is the strength and the value of EFAS $=3.33$ establishes the strategy used in developing the Rongring Stone is an opportunity. Batu Rongring Ecotourism has ODTWA that can be developed. Potential ODTWA found in Batu Rongring are: Sei Musam River, Flora fauna, Community huts, Customs, Caves. Batu Rongring Ecotourism development strategies are: Nature Tourism Attraction, Tourism Cooperation, Ecotourism Training, Capital, Sarpras, Economic Tourism, Traditional Tourism, Perdes, Online Promotion.
\end{abstract}

Keywords: Ecotourism, Batu Rongring, National Park, Musam, SWOT, Mount Leuser

\begin{abstract}
Abstrak
Ekowisata Batu Rongring berada di daerah penyangga Taman Nasional Gunung Leuser (TNGL). Keunikan ekosistem, adat istiadat, flora faunanya membuat Ekowisata Batu Rongring menarik untuk didatangi. Perencanaan dan Pengembangan Ekowisata Batu Rongring harus sesuai dengan karakteristik dan potensi Objek Daya Tarik Wisata Alam (ODTWA) di Batu Rongring. Penelitian ini bertujuan menganalisis perencanaan lanskap dalam pengembangan ekowisata Batu Rongring sebagai peyangga TNGL. Analisis potensi ODTWA untuk Strategi Pengembangan Batu Rongring menggunakan analisis faktor internal (IFAS), faktor eksternal (EFAS) dan Analisis SWOT. Perencanaan lanskap dilakukan dengan melibatkan stakeholder dalam Forum Group Disscusion (FGD). Hasil penilaian dalam pengembangan Ekowisata Batu Rongring diketahui nilai IFAS = 2,71 yang menjadikan strategi dalam pengembangan Batu Rongring adalah kekuatan dan nilai EFAS $=3,33$ menetapkan strategi yang digunakan dalam pengembangan Batu Rongring adalah peluang. Ekowisata Batu Rongring memiliki ODTWA dapat dikembangkan. Potensi ODTWA yang terdapat di Batu Rongring yaitu Sungai Sei Musam, Flora fauna, Pondok masyarakat, Adat istiadat, Gua-Gua. Strategi pengembangan Ekowisata Batu Rongring yaitu Daya Tarik Wisata Alam, Kerjasama wisata, Pelatihan ekowisata, Permodalan, Sarpras, Wisata ekonomis, Wisata khas, Perdes, Promosi online.
\end{abstract}

Kata kunci: Ekowisata, Batu Rongring, Taman Nasional, SWOT, Gunung leuser

\section{Pendahuluan}

Taman Nasional Gunung Leuser merupakan satu dari 54 (lima puluh empat) kawasan konservasi yang terdapat di Indonesia, kawasan ini terletak antara dua provinsi, yaitu Propinsi Aceh dan Sumatera Utara. Pengelolaan Taman Nasional Gunung Leuser berbasis zonasi dengan ditetapkan berdasarkan Surat Keputusan Direktorat Jenderal Perlindungan Hutan dan Konservasi Alam (PHKA) Nomor SK.35/IVSET/2014 tanggal 28 Februari 2014 dengan status penunjukkan Menteri Kehutanan Nomor 276/KptsII/1997 dengan luas \pm 1.094 .692 ha. Kondisi perubahan luasan kawasan berdasarkan penetapan TNGL 
didasarkan Surat Keputusan Menteri Lingkungan Hidup dan Kehutanan Nomor SK.103/MenLHKII/2015 (sebagian TNGL di Provinsi Aceh) dan Nomor SK.4039/Menhut-VII/KUH/2014 (sebagian TNGL di Provinsi Sumatera Utara) menjadi 830.268,95 ha, dengan pembagian zona terdiri atas areal Zona Inti seluas 619.184,80 ha, Zona Rimba seluas 132.732,87 ha, Zona Pemanfaatan seluas 20.371,06 ha, Zona Tradisional seluas 2.359,67 ha, Zona Religi, Budaya dan Sejarah seluas 33, 45 ha, Zona Rehabilitasi seluas 55.185,06 ha dan Zona Khusus seluas 402,04 ha [1]

Permasalahan utama di Taman Nasional Gunung Leuser adalah illegal logging yang berakhir pada perambahan kawasan. Hal ini menyebabkan terbuka dan berubahnya fungsi ekosistem kawasan penunjang kehidupan baik yang langsung pada kawasan berupa habitat flora dan fauna maupun dampak langsung ataupun tidak langsung terhadap masyarakat sekitar dan masyarakat pada umumnya. Akibat yang ditimbulkan bila hutan konservasi terambah antara lain: hilangnya habitat fauna hal ini dapat mengakibatkan kerusakan ekosistem dan terjadinya konflik antara manusia dan satwa, sebagai tempat penyimpanan air dalam volume yang besar/ hutan sebagai pengendali banjir, untuk mencegah terjadinya banjir bandang, longsor dan kekeringan [2].

Beberapa ekosistem hutan konservasi Taman Nasional Gunung Leuser ini sudah mulai terganggu oleh aktifititas illegal logging diantaranya kawasan yang berbatasan langsung, seperti desa Batu Rongring yang sebagian besar wilayahnya berbatasan alam dengan TNGL. Menurut penuturan masyarakat Desa Batu Rongring khususnya yang tinggal sepanjang sungai Sei Musam, mereka dulu sering melakukan pembalakan liar, kemudian bekas areal terbuka tersebut mereka alih fungsikan menjadi perkebunan sawit dan karet. Mereka melakukan aktivitas tersebut karena kondisi tekanan ekonomi dan keterbatasan alternatif mata pencaharian. Bukit Lawang dan Tangkahan merupakan destinasi wisata terdekat dengan Batu Rongring, melihat kondisi sekarang destinasi wisata tersebut sudah dapat meningkatkan perekonomian masyarakat setempat dan menjadi salah satu penghasil PAD dari kunjungan wisata. Memotivasi masyarakat Batu Rongring untuk juga menerapkan pengelolaan pariwisata seperti kedua destinasi wisata tersebut, maka melihat kondisi Batu Rongring alternatif dalam peningkatan perekonomian dengan fungsi kawasan konservasi yang seimbang yaitu Ekowisata.

Salah satu upaya untuk menjaga keberlanjutan kawasan konservasi Taman Nasional Gunung Leuser adalah kegiatan ekowisata, dalam penelitian ini difokuskan pada pengembangan ekowisata di Desa Batu Rongring yang merupakan daerah penyangga Kawasan Konservasi Taman Nasional Gunung Leuser. Desa Batu Rongring merupakan desa yang mempunyai batasan alam yang langsung dengan kawasan TNGL berada Kecamatan Batang Serangan. Peraturan Pemerintah Nomor 28 Tahun 2011 tentang pengelolaan Kawasan Suaka Alam dan Kawasan Pelestarian Alam menjelaskan bahwa kriteria suatu wilayah dapat ditunjuk dan ditetapkan sebagai kawasan taman wisata alam adalah kawasan yang mempunyai daya tarik alam berupa tumbuhan, satwa atau bentangan alam, gejala alam serta formulasi yang unik, mempunyai luas yang cukup, dan keadaan ekosistem di sekitarnya mendukung kegiatan pengembangan pariwisata alam. Peraturan ini menyatakan bahwa kawasan konservasi Taman Nasional hanya dapat dimanfaatkan untuk kegiatan wisata alam dengan persyaratan dan batasan tertentu, dalam hal ini ekowisata.

Pengelolaan yang ingin dicapai dengan kegiatan ekowisata antara lain mengurangi dampak yang yang ditimbulkan oleh kegiatan aktivitas manusia terhadap kawasan konservasi taman nasional, dengan cara menumbuhkan kesadaran lingkungan dan budaya, serta meningkatkan perekonomian dengan pemberdayaan masyarakat lokal. Ekowisata dalam era pembangunan berwawasan lingkungan merupakan suatu misi pengembangan wisata alternatif yang tidak menimbulkan banyak dampak negatif, baik terhadap lingkungan maupun kondisi sosial budaya [3]. Berdasarkan informasi tersebut tujuan penelitian ini adalah mendata potensi dan objek daya tarik ekowisata Batu Rongring yang berguna dalam meningkatkan ekonomi masyarakat desa peyangga Taman Nasional Gunung Leuser.

\section{Metodelogi Penelitian Tempat dan Waktu Penelitian}

Penelitian ini dilakukan di Batu Rongring Desa Sei Musam Kecamatan Bohorok Kabupaten Langkat pada bulan Juni sampai dengan Juli 2019. Alat yang digunakan yaitu alat tulis, kamera, alat perekam, Software ArcGis versi 10.3, Global Positioning System (GPS). Bahan yang digunakan yaitu panduan wawancara, peta image citra SPOT 4 tahun 2019 dan image Google Earth Tahun 2019.

Pengumpulan data potensi daya tarik ekowisata Batu Rongring dilakukan dengan metode kualitatif dengan cara wawancara terstruktur terhadap narasumber kunci (key informan), Focus Group Discussion (FGD) terhadap Balai Besar Taman Nasional Gunung Leuser, Dinas Budaya dan Pariwisata Langkat, KPH I Langkat, Badan Lingkungan Hidup dan Kehutanan Langkat, masyarakat, tokoh masyarakat, 
kepala desa, pemandu wisata dan pemilik homestay, studi literature, observasi lapangan serta panduan pertanyaan Analisis Daerah Obyek dan Daya Tarik Wisata Alam (ODTWA) yang telah disesuaikan dengan lokasi penelitian modifikasi dari Direktorat Jenderal Perlindungan Hutan dan Konservasi Alam [4].

\section{Perencanaan Lanskap}

Perencanaan lanskap dilakukan dalam melindungi dan mempertahankan keaslian alam serta memanfaatkan keunikan tersebut untuk kehidupan manusia. Menurut Ref [5], perencanaan lanskap adalah penyesuaian antara lanskap dan program yang akan dikembangkan untuk menjaga kelestarian ekosistem dan pemandangan lanskap sehingga mencapai penggunaan terbaik. Perencanaan lanskap dituangkan dalam Peta Dasar, Peta Administratif, Peta Topografi dengan menggunakan image citra SPOT 4 Tahun 2012 dan diolah dengan program Arcgis versi 10.3 dan Google Earth Image 2019 yang ada di Kantor Balai Besar TNGL di Medan.

\section{Analisis SWOT}

Analisis SWOT hasil dari lapangan dilakukan untuk mendata keadaan saat ini dan solusi pengembangan Ekowisata Batu Rongring. Analisis SWOT memberikan nilai terhadap faktor eksternal (peluang dan ancaman) yang mempengaruhi dengan nilai faktor internal (kekuatan dan kelemahan) dalam strategi pengembangan Ekowisata Batu Rongring, hasil dari analisis dan tanya jawab/wawancara dengan para pihak maka diambil suatu rekomendasi dalam menentukan alternatif-alternatif strategi. Analisis ini akan menghasilkan empat buah alternatif strategi SO, WO, ST, SW.

Tabel 1. Fasilitas Penunjang di Ekowisata Batu Rongring, Kabupaten Langkat

\begin{tabular}{lcc}
\hline \multicolumn{1}{c}{ Fasilitas Penunjang } & Jumlah & Keterangan \\
\hline Warung Kopi \& Kedai & 10 & Kepemilikan Pribadi \\
Warung Makan & 4 & Kepemilikan Pribadi \\
Camping Ground & 10 & Kepemilikan Umum \\
\hline \multicolumn{1}{c}{ Jumlah Total } & 24 & \\
\hline
\end{tabular}

Sumber: Survei lapangan, 2019

Tabel 2. Fasilitas Penginapan/homestay di Dusun Penampean Ekowisata Batu Rongring, Kabupaten Langkat

\begin{tabular}{ccc}
\hline Nama Penginapan & Jumlah Kamar & Pemilik \\
\hline Homestay Edi Sembiring & 4 & 1 \\
Homestay Jason Kacaribu & 1 & 1 \\
Homestay Boy & 1 & 1 \\
\hline Jumlah Total & 6 & 3 \\
\hline
\end{tabular}

Sumber: Survei lapangan, 2019

\section{Focus Group Discussion}

Faktor-faktor kekuatan internal dan eksternal didapat dengan mengali pendapat-pendapat setiap peserta yang menuliskan semua perihal terkait ekowisata secara umum dan ekowisata Batu Rongring secara khusus. Setelah didapat faktor internal berupa kekuatan dan kelemahan dan faktor eksternal berupa peluang dan ancaman, maka setiap peserta memberikan nilai dengan klasifikasi bobot sebagai berikut: 1 (tidak penting), 2 (agak penting), 3 (penting) dan 4 (sangat penting). Selanjutnya setiap bobot relatif dihitung rating nya dengan klasifikasi rating 1 (tidak baik), 2 (agak baik), 3 (baik), dan 4 (sangat baik) kemudian diambil nilai tengah atau rata-rata setiap indicator.

\section{Hasil dan Pembahasan \\ Perencanaan Lanskap}

Pembahasan perencanaan lanskap didasari atas kesepakatan para pihak tentang tata ruang ekowisata dan kebijakan yang akan menjadi ciri khas ekowisata Batu Rongring. Hasil FGD menyepakati bahwa pengembangan Ekowisata Batu Rongring harus tetap memperhatikan kondisi alam dan budaya leluhur yang ada di Batu Rongring. Tradisi Batu Rongring harus tetap dilestarikan dan para pengunjung harus mau mengikuti aturan-aturan yang telah berlaku di Batu Rongring secara turun temurun.

Menurut Ref [6] menyatakan bahwa transyvalnia autentica mencoba melindungi wilayah dengan keunikan alam dan warisan budaya dengan mempromosikan dan mengembangkan kelestarian mata pencaharian penduduknya. Salah satu proyeknya adalah memastikan bahwa budidaya pertanian dapat bertahan sebagai sumber bahan makanan tradisional dan hasil pertanian dapat diolah bersama antara petani dan pengolah hasil pertanian pada wilayah yang lebih kecil. 
Zona wisata terdiri atas dua zona yaitu wisata masal (mass tourism) dan minat khusus. Zona wisata masal berada di dusun Batu Rongring sampai batas alam hutan konservasi Taman Nasional Gunung Leuser yang dibelah oleh sungai Sei Musam, aktivitas yang dilakukan antara lain tubing (menyusuri aliran sungai dengan menggunakan ban dalam mirip seperti rafting), pondok-pondok tepian sungai untuk bersantai dan berkemah di pinggiran sungai sei musam. Zona wisata minat khusus berupa lintas alam Itracking (menyaksikan bunga Amorphopallus sp, bunga Rafflesia patma, menelusuri goa, mengamati perilaku fauna), bila melakukan tubing harus didampingi pemandu wisata.

Rencana lanskap jalur trecking untuk melihat Objek Daya Tarik Wisata Batu Rongring dapat ditempuh dengan dua paket wisata yang ditawarkan sesuai dengan Gambar 1, dimana Jalur Satu merupakan tracking untuk melihat keunikan goa-goa dengan stalagnit yang dibentuk secara alami oleh alam dan menjadi tempat hidupnya satwa kelelawar dan burung seriti. Jalur ini biasanya dimanfaatkan oleh wisatawan yang berkunjung ke batu rongring dalam waktu yang tidak lama, tracking bisa diselesaikan dalam waktu satu hari, sedangkan Jalur Kedua tambahan dari aktivitas tracking untuk melihat bunga Raflesia Patma, satwa Rusa Unicolor, debit aliran sungai serta bentukan batu yang mirip Grand Canyon. Bila kedua jalur dipilih oleh wisatawan, maka waktu yang dibutuhkan untuk berwisata di Ekowisata Batu Rongring lebih lama dan diantara jalur tersebut terdapat Homestay Edi Sembiring untuk menginap bagi wisatawan.

Pengunjung dari mancanegara berharap agar di Ekowisata Batu Rongring tidak lagi dibangun penginapan atau hotel. Tinggal bersama dengan warga di rumah yang berada di dusun Batu Rongring lebih mereka sukai daripada harus tinggal di hotel. Selain mengenal budaya masyarakat setempat, wisatawan juga dapat melakukan aktivitas bercocok tanam dan mengambil hasil perkebunan seperti sawit dan karet yang merupakan mata pencaharian masyarakat Batu Rongring.

Perencanaan lanskap dengan melibatkan masyarakat lokal dan masyarakat adat merupakan langkah yang tepat. Sesuai dengan pendapat [7] bahwa adopsi pendekatan partisipatif melalui pencantuman secara institusional kerja pemerintah dengan sendirinya saluran komunikasi untuk masyarakat lokal dan masyarakat adat dilibatkan dalam proses pengambilan keputusan. Kesejahteraan masyarakat dan manfaat ekonomis dapat ditingkatkan dengan melibatkan masyarakat dalam sistem pengelolaan kawasan yang dilindungi.

Keberadaan satwa liar yang hidup di Ekowisata Batu Rongring harus diperhatikan. Pengembangan ekowisata diharapkan tetap memperhatikan kehidupan liar terhadap satwa liar. Terjadinya konflik antara satwa liar dan manusia akan mengurangi daya tarik wisata Batu Rongring. Satwa liar yang berpotensi menimbulkan konflik dengan manusia adalah Orangutan Sumatera, Gajah Sumatera, Kedih, Siamang dan Harimau Sumatera. Ekowisata Batu Rongring memiliki daya tarik wisata terdiri panorama alam, bunga bangkai, rafflesia, jelajah goa, air terjun dan satwa liar. Keberadaan satwa liar seperti Orangutan dan siamang tidak menjadi satu-satunya perhatian pengunjung. Kondisi ini merupakan salah satu kelebihan ekowisata Batu Rongring dibandingkan di Bukit Lawang yang tujuan utama pengunjung adalah menyaksikan Orangutan dan di Tangkahan pengunjung dapat memandikan dan ikut patroli bersama Gajah Sumatera.

Keberadaan Rafflesia patma yang berada di dalam kawasan TNGL menjadi pertimbangan tersendiri terhadap Balai Besar TNGL agar menjadikan kawasan pemanfaatan ini dapat menjadi Objek Daya Tarik Wisata (ODTWA). Zona pemanfaatan adalah bagian dari Taman Nasional yang ditetapkan karena letak, kondisi dan potensi alamnya yang terutama dimanfaatkan untuk kepentingan pariwisata alam dan kondisi lingkungan lainnya.

Menurut Ref [7] bahwa indentifikasi lokasi tradisional untuk pemetaan dimaksudkan untuk membuka strategi komunikasi yang lebih luas dengan masyarakat dalam hukum dan kebijakan seperti hak-hak masyarakat adat sering diabaikan. Peta-peta yang sah dapat digunakan oleh masyarakat lokal untuk mengikat dengan pemerintah dan sebaliknya untuk mencegah penebangan liar, perburuan liar, dan perambahan hutan. Keberadaan ekowisata Batu Rongring berada di zona pemanfaatan sesuai dengan revisi zonasi Balai Besar Taman Nasional Gunung Leuser. Zona pemanfaatan terbatas BPTN Wilayah III Stabat masuk dalam Wilayah Seksi V Bohorok dengan zona pemanfaatan seluas 60.166,92 sesuai dokumen zonasi Taman Nasional Gunung Leuser Wilayah III Stabat.

Tata ruang di Dusun Batu Rongring diharapkan tidak mengalami banyak perubahan. Kesempatan membuka usaha bagi masyarakat harus memperhatikan aturan yang akan disepakati bersama nantinya akan dituangkan ke dalam Peraturan Desa (Perdes). Hasil FGD menyepakati bahwa perlu adanya pembangunan untuk tempat warung masyarakat disekitar objek wisata batu Rongring dengan sistem tanah yang bukan dimiliki oleh masyarakat yang ingin berusaha, bisa menyewa kepada masyarakat yang memiliki tanah. Usaha yang bisa dilakukan adalah menyewa tikar, tempat meletakkan ban (tubing), 
berjualan minuman dan makanan ringan. Usaha yang dilakukan oleh masyarakat dusun Batu Rongring perlu diatur oleh Lembaga Pariwisata Relasi sehingga tidak menimbulkan kecemburuan. Menurut Ref [8] dalam penelitiannya tentang pemberdayaan masyarakat disekitar Taman Nasional Gunung Merapi bahwa pemberian modal bantuan usaha dan membangun jaringan usaha harus dikelola oleh kelompok.

Pendapatan akan mengalir pada desa yang dikhususkan untuk wisata, pendapatan akan meningkat sebagai apresiasi atas insentif atas rasionalisasi baru dalam penggunaan sumberdaya tradisional. Pendapatan dari wisata akan berkurang karena sebaliknya yaitu pola pengembangan yang menurunkan sumberdaya tradisional pada tahap lanjutan. Pendapatan dari wisata akan membantu menyatukan para pelaku dan kekuatan yang bertanggung jawab melindungi kawasan yang terancam dalam persaingan pemanfaatan lahan [9].

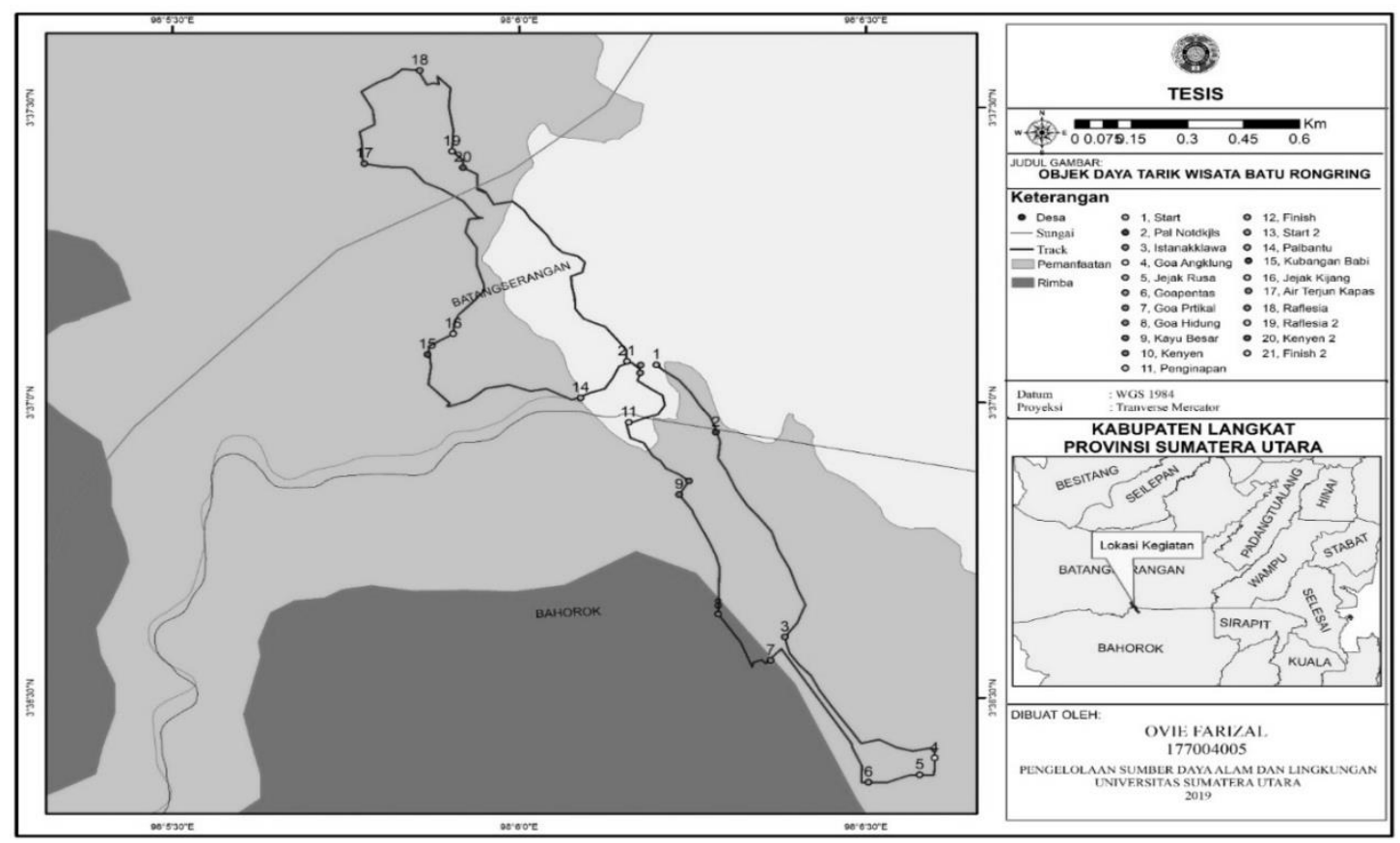

Gambar 1. Peta jalur objek daya tarik wisata Batu Rongring

Sumber: Hasil pengolahan peta Arcgis versi 10.3 (2019)

\section{Sirkulasi Ekowisata Batu Rongring}

Jalur wisata terbentuk dengan adanya jalur penghubung antar ruang dengan obyek wisata yang dialokasikan pada setiap zona [10] . Saat ini sirkulasi Ekowisata Batu Rongring berasal dari satu pintu masuk langsung menuju obyek wisata di sekitar sungai Sei Musam. Kendaraan sepeda motor dan mobil bisa langsung masuk ke titik tujuan pengunjung di sungai Sei Musam melalui pemukiman atau melewati jalan kebun yang menuju titik yang sama. Lokasi parkir masih berada di pekarangan masyarakat, besaran biaya parkir sudah diatur oleh Lembaga Pariwisata Relasi untuk roda dua Rp. 5.000/hari dan roda empat Rp. 10.000/hari. Wisatawan massal biasanya hanya sampai di sekitar camping ground sekitar pinggiran sungai Sei Musam hingga pondok Lembaga Pariwisata Batu Rongring. Jalur dari pintu gerbang menuju tempat parkir merupakan jalur primer dari tempat parkir menuju obyek di pinggiran sungai Sei Musam dan seberangnya sampai penginapan Homestay Edi Sembiring. Hasil FGD merekomendasikan untuk segera menentukan lokasi parkir, hal ini untuk menentukan sirkulasi wisata. Terdapat satu alternatif penempatan lokasi parkir, yang berada diantara pemukiman, kebun milik Kidam dan Homestay Boy sesuai dengan Gambar 2. 


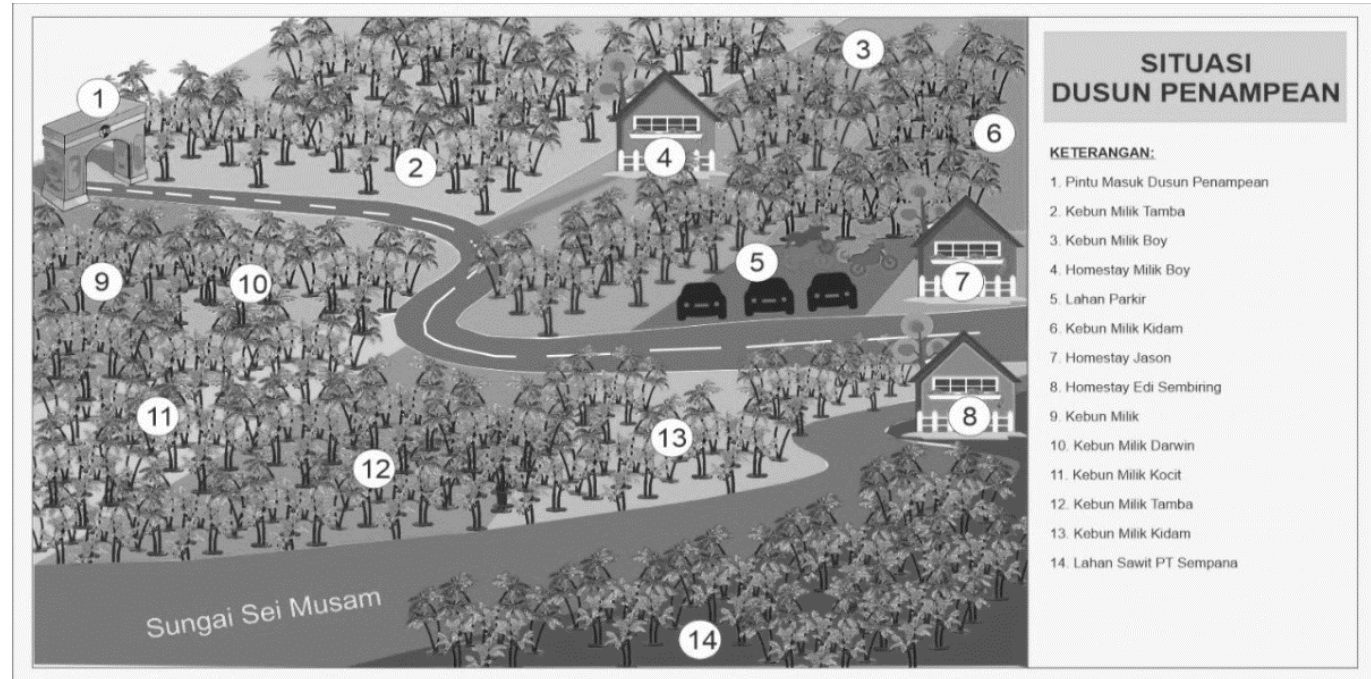

Gambar 2. Situasi Dusun Penampean

Sumber: Hasil pengolahan data dilapangan, 2019

\section{Rencana Pembangunan Sarana dan Prasarana}

Pengembangan daerah yang belum berpotensi menjadi daerah berpotensi sebagai objek daya tarik wisata (ODTWA) diperlukan upaya-upaya promosi dan pemasaran guna menarik potensi pasar, memperkecil kendala aksesibilitas melalui penyediaan sarana prasarana moda transportasi, meningkatkan pengelolaan dan pelayanan sesuai standar pelayanan, melakukan pemenuhan terhadap standar akomodasi yang diperlukan, dan meningkatkan diversifikasi atraksi wisata. Berdasarkan kondisi objektif pengembangan ekowisata saat ini maka strategi pengembangan yang dapat diterapkan yaitu strategi pesimis melalui upaya penataan ruang wisata, pengembangan manajemen atraksi, pengembangan pomosi dan pemasaran, pengembangan regulasi dan organisasi pengelola ekowisata, dan menciptakan situasi keamanan yang kondusif baik di dalam maupun luar kawasan wisata [11] .

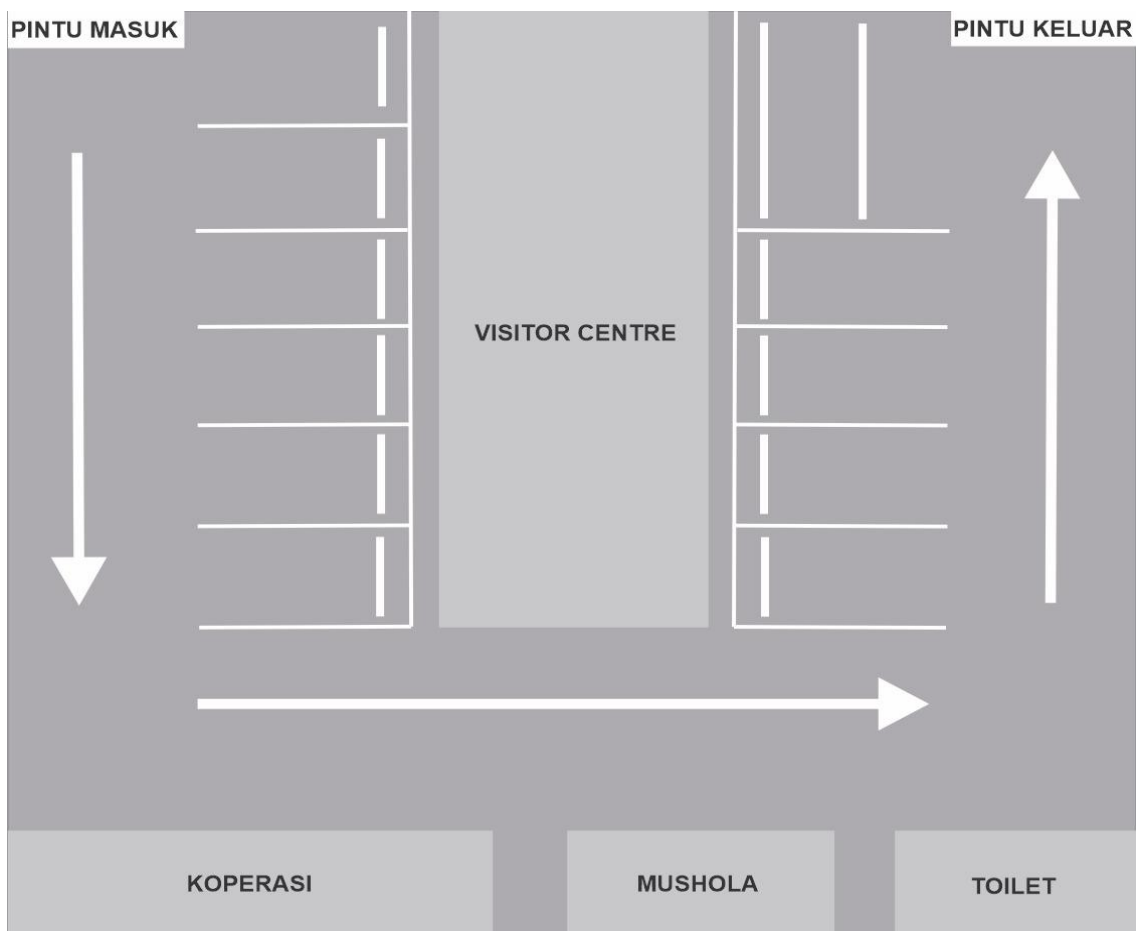

Gambar 3. Denah Pembangunan Areal Parkir, Visitor Centre, Mushola, dan Toilet Sumber: Hasil FGD dilapangan, 2019

Ketiadaan fasilitas seperti tempat sampah, lokasi parkir, toilet umum, visitor center, musholla, koperasi souvernir, klinik kesehatan, ruang informasi dan pos keamanan. Pembangunan fasilitas umum 
tersebut sangat diperlukan dalam pengembangan ekowisata Batu Rongring. Dari hasil wawancara dan diskusi rencana pembangunan lokasi parkir, lokasi visitor center dan toilet sesuai dengan Gambar 3.

Lokasi parkir lengkap dengan visitor center, mushola toilet umum merupakan prioritas untuk dibangun. Pembangunan dengan tetap mempertahankan kondisi asli, seminimal mungkin melakukan penebangan pohon. Parkir berada di lahan masyarakat dengan sistem pembagian hasil yang diatur dalam peraturan desa. Saat ini bila hari-hari libur dengan kunjungan wisatawan yang ramai, setiap kendaraan roda empat dipungut uang kebersihan, parkir dan untuk pengelola sejumlah Rp. 10.000 dan Rp.5000 untuk kendaraan roda dua.

Media interpretasi juga perlu dilengkapi seperti penanda (signage), leaflet dan peta jalur untuk jenis wisata edukatif perlu disusun paket-paket wisata yang lebih menarik [12]. Ekowisata Batu Rongring, masih belum memiliki media interpretasi seperti tersebut. Pengadaan media interpretasi tersebut sangat diperlukan sebagai penunjuk atau pedoman dalam berwisata.

Lokasi yang sering dikunjungi satwa liar perlu diberi tanda dengan jelas namun tidak merusak pemandangan. Tanda-tanda tersebut akan memudahkan bagi para pengunjung yang ingin menyaksikan satwa liar. Selain tanda lokasi satwa liar juga perlu papan informasi tentang saat-saat kemunculan satwa liar sehingga pengunjung dapat mengatur waktu untuk dapat melihat satwa liar secara langsung.

Tanda-tanda untuk jalur evakuasi apabila terjadi bencana alam seperti banjir bandang, gempa bumi juga harus dibuat. Lokasi tempat pengumpulan masa biasanya di lapangan terbuka seperti lahan parkir sehingga memudahkan dalam pengumpulan masyarakat dan melakukan evakuasi.

Menurut Ref [13] bahwa dalam pengembangan ekowisata dalam perencanaannya perlu melakukan studi formal atau informal dari karakteristik msyarakat setempat supaya bisa mendapatkan gambaran yang jelas orang-orang yang bisa dilibatkan. Terbentuknya Lembaga Pariwisata Relasi mengindikasikan bahwa niat untuk mengembangkan ekowisata datang dari inisiatif masyarakat, dengan keterlibatan dari seluruh warga dusun.

\section{Analisis Faktor Internal dan Eksternal Potensi Obyek Daya Tarik Wisata}

Setelah dilakukan pengamatan lokasi kawasan ekowisata Batu Rongring diperoleh beberapa aktivitas-aktivitas wisata yang dapat dikembangkan. Aktivitas wisata terdapat dalam kawasan konservasi Taman Nasional Gunung Leuser yaitu zona pemanfaatan yang berbatasan langsung dengan Desa Sei Musam Dusun Penampean. Hasil analisis objek daya tarik wisata alam di Batu Rongring menunjukkan nilai 2,71. Nilai ini memperlihatkan bahwa objek daya tarik wisata kawasan Batu Rongring sangat layak dan sesuai untuk dijadikan kawasan ekowisata.

Ref [14] menyatakan hasil perhitungan skor terhadap analisis faktor-faktor internal dengan nilai sebesar 2,82 diketahui bahwa faktor-faktor internal di Ekowisata Batu Katak merupakan kekuatan. Adanya kesamaan antara Ekowisata Batu Katak dan Batu Rongring tidak lain disebabkan oleh kesamaan karakteristik suku, budaya dan adanya kedekatan tempat dilokasi Kabupaten Langkat.

\section{Analisis Faktor-Faktor Internal Ekowisata Batu Rongring}

Hasil analisis IFAS di Ekowisata Batu Rongring menunjukkan faktor-faktor internal yang menjadi kekuatan (strength) dan kelemahan (weakness) adalah:

\begin{tabular}{|c|c|}
\hline $\begin{array}{l}\text { Kekuatan } \\
\text { (Strenghts) }\end{array}$ & $\begin{array}{l}\text { Kelemahan } \\
\text { (Weakness) }\end{array}$ \\
\hline $\begin{array}{l}\text { Pertunjukkan alami kawasan konservasi berupa } \\
\text { pemandangan alam berupa Gua Stalagnit, Gua Sarang } \\
\text { Burung Walet, Sungai Sei Musam, Air Terjun, dan } \\
\text { hutan alam dengan vegetasi yang masih alami }\end{array}$ & $\begin{array}{l}\text { Bantuan dana usaha masih minim sehingga tingkat } \\
\text { produksi rendah, potensi pengembangan usaha untuk } \\
\text { mendukung Ekowisata Batu Rongring sudah ada yaitu } \\
\text { produk ukiran dari bambu dan anyam-anyaman }\end{array}$ \\
\hline $\begin{array}{l}\text { Keindahan dan keunikan ekosistem, flora dan fauna. } \\
\text { Daya tarik satwa liar yang masih terdapat di Hutan } \\
\text { Konservasi Taman Nasional Gunung Leuser seperti } \\
\text { Harimau sumatera, Kucing Hutan, Orangutan, Monyet } \\
\text { ekor panjang, Beruang madu, serta terdapat beberapa } \\
\text { jenis flora seperti Bunga Rafflesia Patma dan Bunga } \\
\text { Bangkai yang masih terjaga keberadaannya di alam }\end{array}$ & $\begin{array}{l}\text { Kurangnya kesadaran masyarakat tentang ekowisata, } \\
\text { masyarakat yang belum paham manfaat dari daerah } \\
\text { yang dijadikan kawasan wisata akan melakukan } \\
\text { kegiatan-kegiatan yang dapat menyebabkan } \\
\text { keyamanan wisatawan tergangu, salah satunya dengan } \\
\text { membuntuti, mengkerumuni bila ditempat ramai }\end{array}$ \\
\hline $\begin{array}{l}\text { Suku utama yang mendiami Desa Sei Musam adalah } \\
\text { Suku Karo, Suku ini memiliki kearifan lokal seperti } \\
\text { pemanfaatan tumbuhan di alam dalam pengobatan, } \\
\text { membuat anyaman tikar dan bangunan rumah mereka } \\
\text { yang masih menggunakan bahan-bahan yang mudah } \\
\text { ditemukan di alam. Ada beberapa wisatawan yang }\end{array}$ & $\begin{array}{l}\text { Sarana dan prasarana masih belum lengkap, penanda/ } \\
\text { penunjuk lokasi serta papan pengumuman belum ada, } \\
\text { lokasi camping ground belum sesuai peruntukkannya, } \\
\text { gerbang masuk kawasan ekowisata belum ada, tempat } \\
\text { pembuangan sampah dan koperasi yang menjual } \\
\text { produk-produk hasil dari masyarakat belum ada }\end{array}$ \\
\hline
\end{tabular}


selalu menyukai aktivitas kehidupan sosial di pedesaan

Dukungan dari pemerintah untuk saat ini yang telah ada adalah bangunan jalan menuju ke Batu Rongring dari Tangkahan telah dilakukan pengerasan jalan untuk pengaspalan begitu juga jalan yang melalui Bukit Lawang. Aksesibilitas jalan yang baik apalagi menghubungkan 2 (dua) destinasi wisata yang terlebih dahulu terkenal tersebut secara langsung dapat meningkatkan kunjungan wisatawan ke kawasan Ekowisata Batu Rongring. Apalagi di daerah ini sering diadakan acara dalam penyambutan tamu ataupun acara adat istiadat pernikahan serta pemakaman
Kurangnya sumber daya manusia pemandu wisata, kualitas sumber daya manusia yang berusia produktif tidak terlalu menyukai menjadi pemandu/pengelola wisata, mereka lebih terlibat dalam pertanian, perkebunan, perdagangan dan sebagian lebih memilih merantau ke kota

$\begin{array}{lcccc}\text { Pemasaran } & \text { Ekowisata } & \text { Batu } & \text { Rongring } & \text { kurang } \\ \text { terpublikasi, bersifat perorangan serta } & \text { sangat } \\ \text { dipengaruhi oleh wisatawan yang sudah } & \text { pernah } \\ \text { berkunjung ke Batu Rongring khususnya dari Medan }\end{array}$

Penilaian terhadap skor faktor-faktor internal didapat nilai 2,71, dengan begitu faktor internal di ekowisata Batu Rongring adalah kekuatan, dalam pengembangan ekowisata Batu Rongring pengelola harus menggunakan strategi kekuatan dengan Tabel 3.

Tabel 3. Matrik IFAS Pengembangan Ekowisata Batu Rongring

\begin{tabular}{|c|c|c|c|}
\hline Faktor-Faktor Strategi Internal & Bobot & Rating & Skor \\
\hline \multicolumn{4}{|l|}{ Kekuatan (Strenghts) } \\
\hline $\begin{array}{l}\text { 1. Atraksi alami kawasan konservasi dan lingkungan } \\
\text { sekitarnya masih terjaga }\end{array}$ & 0.14 & 4 & 0.55 \\
\hline $\begin{array}{l}\text { 2. Keindahan dan keunikan ekosistem, flora dan } \\
\text { fauna }\end{array}$ & 0.15 & 4 & 0.61 \\
\hline 3. Kearifan lokal (local wisdom) & 0.09 & 3 & 0.27 \\
\hline 4. Dukungan pemerintah & 0.15 & 4 & 0.61 \\
\hline Sub Total Kekuatan & & & 2.03 \\
\hline Kelemahan (Weakness) & Bobot & Rating & Skor \\
\hline 1. Kurangnya modal usaha & 0.06 & 1 & 0.06 \\
\hline $\begin{array}{llll}\text { 2. } & \begin{array}{l}\text { Kurangnya } \\
\text { ekowisata }\end{array} & \text { kesadaran masyarakat tentang } \\
\end{array}$ & 0.09 & 1 & 0.09 \\
\hline 3. Fasilitas wisata yang masih kurang/ belum lengkap & 0.11 & 1 & 0.11 \\
\hline $\begin{array}{lllll}\text { 4. Kurangnya Sumber Daya } & \text { Manusia pelaku } \\
\text { ekowisata }\end{array}$ & 0.09 & 2 & 0.18 \\
\hline $\begin{array}{l}\text { 5. Masih minimnya promosi yang dilakukan oleh } \\
\text { pengelola terhadap Kawasan Ekowisata Batu } \\
\text { Rongring }\end{array}$ & 0.12 & 2 & 0.24 \\
\hline Sub Total Kelemahan & & & 0.68 \\
\hline Total Keseluruhan & 1.00 & & 2.71 \\
\hline
\end{tabular}

Sumber: Hasil pengolahan data Forum Group Disscusion (FGD), 2019

Ket:

Apabila total rata-rata skor berada diatas 2,5 maka hal ini menunjukkan bahwa pengelola Batu Rongring telah memanfaatkan kekuatan dengan baik serta disisi lain mereka juga mampu meminimalkan kelemahan secara bersamaan. Apabila total rata-rata skor dibawah 2,5 hal ini menunjukkan bahwa pengelola Batu Rongring tidak mampu memanfaatkan kekuatan yang ada serta tidak mampu meminimalkan kelemahan yang dimiliki (Sumber: [19])

Berdasarkan Tabel 3, dilihat total nilai rataan skor kawasan Batu Rongring sebesar 2,71 (diatas 2,5). Skor ini mempengaruhi pengelolaan kawasan Batu Rongring agar memanfaatkan kekuatan dan meminimalkan kelemahan yang dimiliki oleh kawasan Batu Rongring dalam pengembangan ekowisata. Melihat tabel faktor internal diatas, sehingga dapat disimpulkan kekuatan dalam pengembangan kawasan Batu Rongring dengan skor 0,61 dan 0,55 terdapat pada tiga kriteria yaitu keindahan dan keunikan ekosistem flora dan fauna, dukungan pemerintah, daya tarik wisata alam dan lingkungan sekitarnya masih alami. Sebagai desa peyangga Taman Nasional Gunung Leuser Batu Rongring dapat dikembangkan untuk ekowisata dengan memperhatikan kaidah-kaidah pelestarian alam. 
Matrik faktor internal dapat melihat kelemahan yang terjadi di kawasan Batu Rongring. Sesuai Tabel 3 penghambat dalam pengembangan ekowisata Batu Rongring dan menjadi kelemahan utama oleh Batu Rongring dengan skor 0,06 terdapat pada satu kriteria yaitu kurangnya modal usaha. Modal usaha diperlukan dalam pengembangan sarana prasarana pendukung ekowisata Batu Rongring, masih banyak lahan yang terdapat sekitar sungai Sei Musam yang dimiliki oleh perorangan peruntukannya hanya untuk berkebun, sementara apabila digunakan oleh bukan pemilik akan dikenakan sewa. Selain modal usaha, kurangnya kesadaran masyarakat tentang ekowisata menjadi penghambat dalam meningkatkan kunjungan ke Batu Rongring, karena setiap kunjungan yang dilakukan oleh wisatawan, tidak mendapatkan kenyamanan dan suasana yang diinginkan oleh wisatawan.

Menurut Ref [15] keberlanjutan sebuah destinasi mempertimbangkan aspek ekonomi, sosial, dan lingkungan. Masyarakat lokal diberikan pelatihan, pendidikan dan keterlibatan langsung dalam mengembangkan ekowisata Batu Rongring, sehingga memberikan dampak positif bagi ekonomi dan menjamin keberlangsungan pariwisata di suatu kawasan.

Ekowisata merupakan alat konservasi dan dapat meningkatkan kesejahteraan masyarakat melalui keterlibatan masyarakat dalam kegiatan pengelolaan dan pengembangan Taman Nasional, pembagian pendapatan, pendidikan tentang konservasi, dan program-program peningkatan kepekaan terhadap ekowisata, dan pengembangan infrastruktur bagi masyarakat di Bale Moutains National Park [16] . Kondisi Ekowisata Batu Rongring akan berkembang dengan keterlibatan masyarakat lokal disamping adanya dukungan dari sarana prasarana untuk kenyamanan dan kemudahan menikmati akses wisata alam di Batu Rongring

\section{Analisis Faktor-Faktor Eksternal Ekowisata Batu Rongring}

Hasil analisis EFAS di ekowisata Batu Rongring menunjukkan faktor-faktor eksternal yang menjadi peluang (opportunities) dan ancaman (treath) adalah:

\begin{tabular}{|c|c|}
\hline $\begin{array}{c}\text { Peluang } \\
\text { (Opportunities) }\end{array}$ & $\begin{array}{c}\text { Ancaman } \\
\text { (Treath) }\end{array}$ \\
\hline $\begin{array}{l}\text { Peraturan Desa (Perdes) yang mengacu pada Peraturan } \\
\text { Manteri dapat menjadi acuan bagi Pemda dan } \\
\text { pengelola wisata untuk pengembangan Ekowisata Batu } \\
\text { Rongring }\end{array}$ & $\begin{array}{l}\text { Perang dagang antara Negara maju berpengaruh } \\
\text { terhadap Negara berkembang dalan meningkatkan } \\
\text { kunjungan wisatawan. Akibat Perang dagang antara } \\
\text { Amerika dan China. Saat ini juga nilai dari sumber } \\
\text { perkebunan seperti sawit dan karet mengalami } \\
\text { penurunan disebabkan oleh isu tentang sawit yang } \\
\text { tidak legal karena dihasilkan dari merusak hutan } \\
\text { konservasi dan pembakaran lahan secara besar-besaran } \\
\text { untuk pembukaan lahan sawit baru. Keadaan ini } \\
\text { mempengaruhi jumlah pengunjung, serta } \\
\text { ketidakstabilan kondisi dalam negeri menjadi } \\
\text { hambatan dalam investasi di Indonesia }\end{array}$ \\
\hline
\end{tabular}

Kondisi keamanan dalam negeri sangat berpengaruh terhadap intensitas kunjungan wisata ke Indonesia. Hal ini sangat terasa sebelum peristiwa bom bali, sedangkan setelah terjadinya peristiwa bom bali beberapa Negara mengeluarkan travel warning terhadap Negara Indonesia.
Persaingan jenis pariwisata yang sama di Kabupaten Langkat, melihat destinasi wisata yang telah dijadikan tujuan utama dari Pemerintah Daerah Sumatera Utara melalui Dinas Pariwisata adalah Tangkahan dan Bukit Lawang, yang lokasinya berdekatan dengan Ekowisata Batu Rongring, sangat berpengaruh terhadap kunjungan ke Ekowisata Batu Rongring yang masih baru dan belum terkenal

Aktivitas illegal dalam kawasan konservasi tidak terjadi sebab tegaknya hokum dan kesadaran dari masyarakat akan manfaat ekonomi yang didapat dari menjaga kawasan konservasi Taman Nasional.
Masuknya budaya negatif yang dibawa oleh wisatawan, kegiatan-kegiatan wisata yang langsung berhubungan dengan pengunjung pariwisata secara langsung dapat berdampak terhadap pertukaran budaya positif maupun negatif, yang sangat dikhawatirkan perubahan di masyarakat desa yang mudah menerima perubahan, kebiasaan masyarakat desa berupa normanorma tersebut

Posisi antara destinasi wisata yang berada di Kabupaten Langkat yang sudah dikenal terlebih dahulu. Membuat paket perjalanan di 3 (tiga) lokasi tersebut dengan keunikan masing-masing 
Hasil perhitungan skor terhadap faktor-faktor eksternal dengan nilai sebesar 3.33. Diketahui bahwa faktor-faktor eksternal di Ekowisata Batu Rongring merupakan peluang. Strategi yang dapat digunakan adalah memanfaatkan peluang dalam pengembangan Ekowisata Batu Rongring. Peranan pemerintah yang mendukung pengembangan ekowisata merupakan peluang yang harus dimanfaatkan. Hal ini sesuai dengan penelitian [17] dan [18] bahwa dukungan pemerintah daerah dengan berbagai kebijakan dan program pengembangan ekowisata. Pedoman dalam pengembangan ekowisata sudah diatur oleh Peraturan Menteri dalam Negeri Nomor 33 Tahun 2009 tentang Pengembangan Ekowisata di Daerah.

Tabel 4. Matrik EFAS Pengembangan Ekowisata Batu Rongring

\begin{tabular}{|c|c|c|c|}
\hline Faktor-Faktor Strategi Eksternal & Bobot & Rating & Skor \\
\hline \multicolumn{4}{|l|}{ Peluang (Opportunities) } \\
\hline $\begin{array}{l}\text { 1. Peraturan Desa yang mengacu pada } \\
\text { Paeraturan Menteri dalam pengelolaan } \\
\text { ekowisata }\end{array}$ & 0.18 & 3 & 0.53 \\
\hline 2. Kondisi politik stabil & 0.16 & 4 & 0.63 \\
\hline $\begin{array}{l}\text { 3. Ekowisata Batu Rongring berdekatan } \\
\text { dengan wisata yang sudah terkenal } \\
\text { Tangkahan dan Bukit Lawang }\end{array}$ & 0.16 & 3 & 0.47 \\
\hline 4. Penegakan Hukum (TIPIHUT) & 0.18 & 4 & 0.71 \\
\hline Sub Total Peluang & & & 2.33 \\
\hline Ancaman (Threat) & Bobot & Rating & Skor \\
\hline 1. Kondisi ekonomi nasional & 0.14 & 4 & 0.55 \\
\hline $\begin{array}{l}\text { 2. Persaingan jenis pariwisata yang sama di } \\
\text { Kabupaten Langkat }\end{array}$ & 0.14 & 2 & 0.27 \\
\hline $\begin{array}{l}\text { 3. Masuknya budaya negatif yang dibawa oleh } \\
\text { wisatawan }\end{array}$ & 0.06 & 3 & 0.18 \\
\hline Sub Total Ancaman & & & 1.00 \\
\hline Total Keseluruhan & 1.00 & & 3.33 \\
\hline
\end{tabular}

Sumber: Hasil pengolahan data Forum Group Disscusion (FGD), 2019

Ket:

Apabila total rata-rata skor berada diatas 2,5 maka hal ini menunjukkan bahwa pengelola Batu Rongring telah memanfaatkan peluang yang ada dengan baik serta disisi lain mereka juga mampu meminimalkan ancaman secara bersama-sama. Apabila total rata-rata skor dibawah 2,5 hal ini menunjukkan bahwa pengelola Batu Rongring tidak mampu memanfaatkan peluang yang ada serta tidak mampu meminimalkan ancaman dari luar. (Sumber [19])

Dari Tabel 4 faktor eksternal (EFAS) diketahui kondisi eksternal kawasan Batu Rongring. Pengumpulan data faktor eksternal yang meliputi peluang dan ancaman yang dimiliki oleh kawasan Batu Rongring diperoleh dari hasil observasi dan diskusi dengan beberapa stakeholders, yaitu BBTNGL Provinsi Sumatera Utara, Kesatuan Pemangkuan Hutan (KPH) Wil. I Langkat, dan Lembaga Pariwisata (Relasi) Batu Rongring.

Berdasarkan Tabel 4 terdapat rerata nilai total skor faktor eksternal Batu Rongring adalah 3,33 (diatas 2,5) maka pengelola Batu Rongring dapat memanfaatkan peluang yang ada serta meminimalkan ancaman. Menurut matriks EFAS diatas, opportunities terbaik ada 3 (tiga) kriteria dengan skor 0,71 dan 0,53, yaitu adanya Peraturan Desa yang mengacu pada Peraturan Menteri dalam pengembangan pengelola ekowisata di daerah, Peraturan Menteri ini bisa menjadi acuan bagi Pemerintah daerah dalam pengembangan ekowisata di kawasan Batu Rongring. Kemudian penegakan hukum tindak pidana kehutanan (Tipihut) menjadikan kawasan Taman Nasional Gunung Leuser menjadi terjaga kelestariannya, sehingga sebagian objek daya tarik wisata (ODTWA) yang berada dikawasan akan tetap terjaga kealamiannya, dan kondisi politik stabil sangat berpengaruh terhadap kunjungan wisatawan luar negeri ke kawasan Ekowisata Batu Rongring.

Tabel 4 juga menunjukkan nilai skor faktor ancaman di kawasan Batu Rongring. Ancaman terbesar dengan skor 0,55 yaitu kondisi ekonomi nasional hal ini dibuktikan dengan kejadian meledaknya bom Bali serta beberapa gereja yang menyebabkan beberapa negara mengeluarkan larangan berkunjung ke Indonesia (Travel Warning). Ancaman besar lainnya dengan skor 0,27 yaitu persaingan jenis pariwisata yang sama di Kabupaten Langkat. Apabila Batu Rongring tidak dilakukan promosi dengan gencar maka pariwisata di Batu Rongring akan tertinggal dengan pariwisata yang sudah ada terlebih dahulu di Kabupaten Langkat, ditambah lagi pariwisata ini sudah menjadi tujuan wisata Sumatera Utara melalui Dinas Kebudayaan dan Pariwisata. 


\section{Analisis SWOT}

Hasil analisis faktor-faktor internal dan eksternal disintesis dalam Matrik SWOT untuk merumuskan alternatif-alternatif strategi yang akan dijadikan pedoman dalam pengembangan Ekowisata Batu Rongring.

Tabel 5. Matrik SWOT

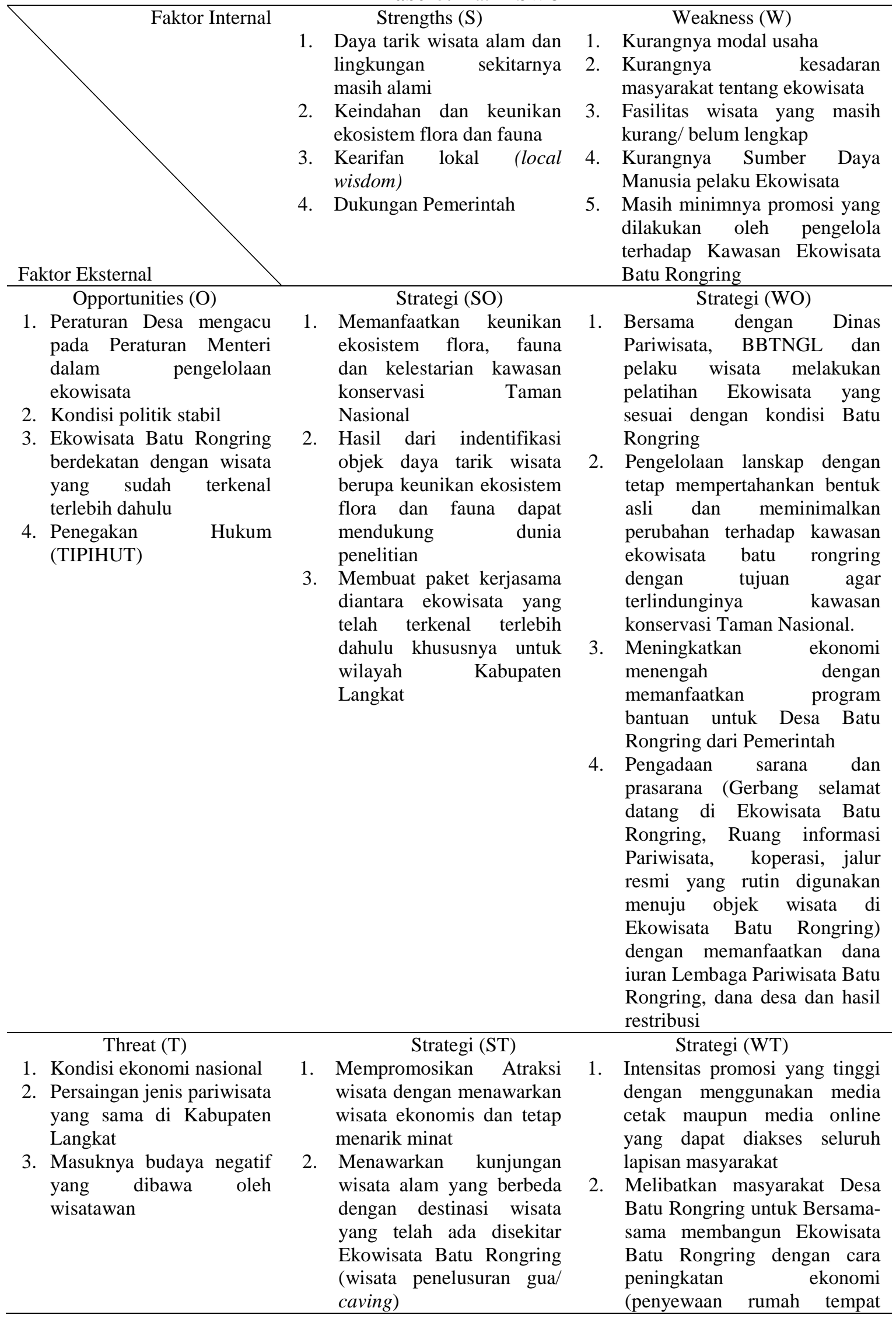




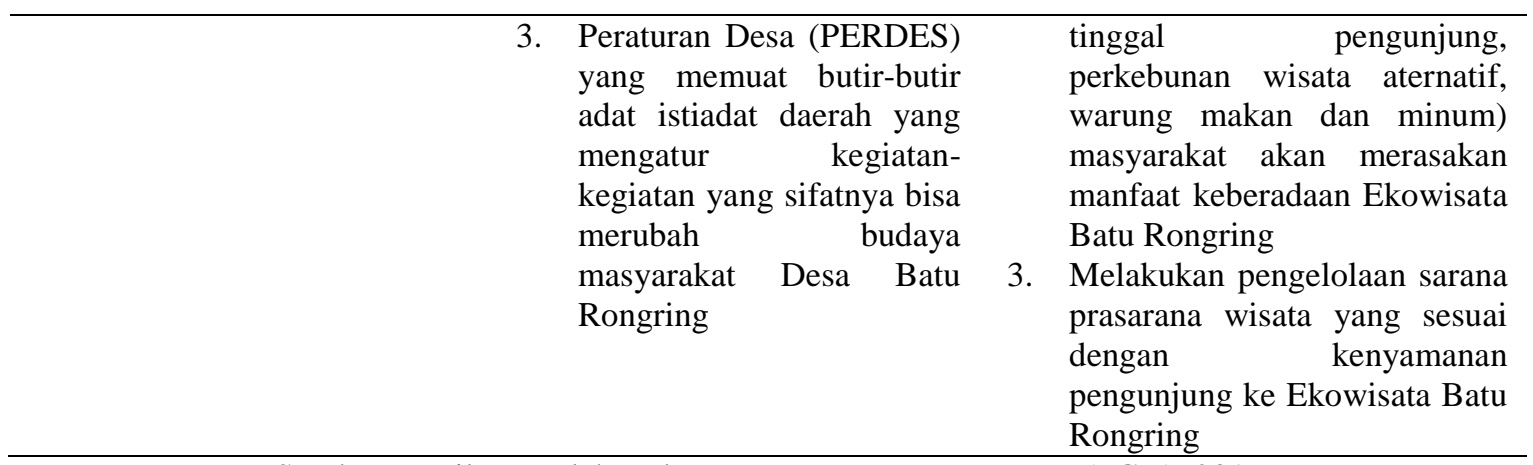

Sumber: Hasil Pengolahan data Forum Group Disscusion (FGD), 2019

Berdasarkan matrik analisis SWOT diatas, maka dapat disimpulkan strategi SO, WO, ST, WT seperti berikut:

\section{Strategi SO (Strenght Opportunities)}

Memanfaatkan keunikan ekosistem flora, fauna dan kelestarian kawasan konservasi Taman Nasional; Hasil dari indentifikasi objek daya tarik wisata berupa keunikan ekosistem flora dan Menggunakan daya tarik wisata alam, berupa keunikan ekosistem flora dan fauna dapat mendukung dunia penelitian; Membuat paket kerjasama antara ekowisata yang telah terkenal terlebih dahulu khususnya untuk wilayah Kabupaten Langkat.

\section{Strategi WO (Weakness Opportunities)}

Bersama dengan Dinas Pariwisata, BBTNGL dan pelaku wisata melakukan pelatihan ekowisata yang sesuai dengan kondisi Batu Rongring; Pengelolaan lanskap dengan tetap mempertahankan bentuk asli dan meminimalkan perubahan terhadap kawasan ekowisata batu rongring dengan tujuan agar terlindunginya kawasan konservasi Taman Nasional; Meningkatkan ekonomi menengah dengan memanfaatkan program bantuan untuk desa Batu Rongring dari pemerintah; Pengandaan sarana dan prasarana (Gerbang selamat datang di Ekowisata Batu Rongring, Ruang Informasi, Pariwisata, Koperasi, jalur resmi yang rutin digunakan menuju objek wisata di ekowisata Batu Rongring) dengan memanfaatkan dana iuran Lembaga Pariwisata Batu Rongring, dana desa dan hasil restribusi.

3. Strategi ST (Strenghts Threats)

Mempromosikan atraksi wisata dengan menawarkan wisata ekonomis dan tetap menarik minat; Menawarkan kunjungan wisata alam yang berbeda dengan destinasi wisata yang telah ada disekitar Ekowisata Batu Rongring (wisata penelusuran gua/caving); Peraturan Desa (PERDES) yang memuat butir-butir adat istiadat daerah yang mengatur kegiatan-kegiatan yang sifatnya bisa merubah budaya masyarakat Desa Batu Rongring.

\section{Strategi WT (Weakness Threats)}

Intensitas promosi yang tinggi dengan menggunakan media cetak maupun media online yang dapat diakses seluruh lapisan masyarakat; Melibatkan masyarakat Desa Batu Rongring untuk bersama-sama membangun ekowisata Batu Rongring dengan cara peningkatan ekonomi (penyewaan rumah tempat tinggal pengunjung, perkebunan wisata alternatif, warung makan dan minum) masyarakat akan merasakan manfaat keberadaan Ekowisata Batu Rongring; Melakukan pengelolaan sarana prasarana wisata yang sesuai dengan keyamanan pengunjung ke Ekowisata Batu Rongring

\section{Kebijakan pengembangan Ekowisata Batu Rongring}

Berdasarkan hasil analisis SWOT dan perencanaan lanskap, maka kebijakan pengembangan Ekowisata Batu Rongring dapat dirumuskan sebagai berikut: 


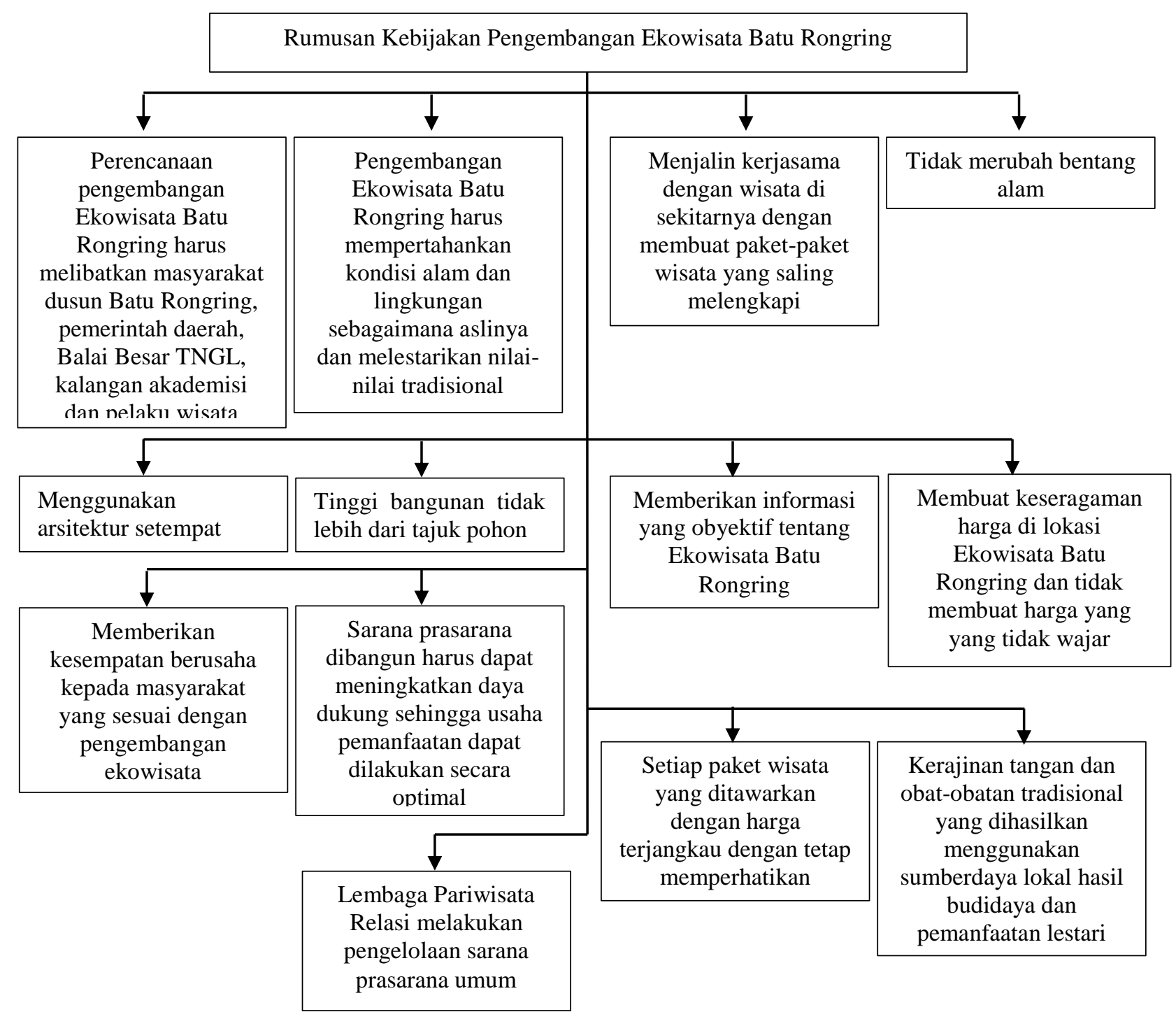

\section{Kesimpulan}

Objek daya tarik wisata alam yang berpotensi sebagai daya tarik Ekowisata Batu Rongring yaitu Sungai Sei Musam, flora dan fauna, pondok dan perkebunan masyarakat, Wisata Adat Istiadat dan Jelajah Desa dan Gua-gua di Batu Rongring. Perencanaan lanskap di Ekowisata Batu Rongring harus mengikuti kaidah-kaidah Peraturan Perundang-undangan yang berlaku. Perumusan strategi pengembangan ekowisata Batu Rongring menghasilkan strategi-strategi, yaitu (1) keindahan dan keunikan Kawasan Ekowisata Batu Rongring dapat menjadi alternatif lokasi ekowisata di Kabupaten Langkat khususnya dan Propinsi Sumatera Utara umunya, (2) lembaga Pariwisata Batu Rongring harus bersinergi dengan berbagai stakeholders (Pemerintah, LSM dan Masyarakat) dalam merencanakan dan melaksanakan kegiatan ekowisata di Batu Rongring, (3) memperluas promosi baik didalam negeri maupun ke luar negeri dengan menggunakan sarana travel agent atau website online, (4) menjadikan masyarakat yang tergabung dalam Lembaga Pariwisata Batu Rongring sebagai pengerak pariwisata dengan menjadi sebagai pemandu perjalanan; dan (5) kesadaran masyarakat harus ditingkatkan dalam memahami tentang ekowisata.

\section{Referensi}

[1] BBTNGL, Penataan Zona Pengelolaan Taman Nasional Gunung Leuser Provinsi Aceh dan Sumatera Utara 2019. 2019:

[2] BBTNGL, Rencana Pemulihan Ekosistem Taman Nasional Gunung Leuser Provinsi Aceh dan Sumatera Utara Tahun 2019 - 2023. 2019.

[3] Hadi SP. Dimensi Lingkungan Perencanaan Pembangunan. Gajah Mada University Press. Yogyakarta. 2007. 
[4] Ditjen PHKA, Pedoman analisis daerah operasi obyek dan daya tarik wisata alam 2003. Direktorat Wisata Alam dan Pemanfaatan Jasa Lingkungan Bogor, 2003:.

[5] Gold, S,M.. Recreation Planning and Design. New York : McGraw Hill Book Company. 1980

[6] Barna, C., Epure, M., Vasilescu, R.. Ecotourism-Conservation of the Natural and Cultural Haritage. REASER. 2011

[7] Ami, J., Hamzah, A. Incorporating Sacred Places and Traditional Value in the Management of Protected Area for Conservation and Ecotourism. Jounal of Hospitality and Tourism. 10 (1): pp. 53-64, 2013.

[8] Garjita, I, P., Susilowati, I., Soeprobowati, T, R. "Strategi Pemberdayaan Masyarakat Kelompok Tani Hutan Ngudi Makmur di Sekitar Taman Nasional Gunung Merapi.” Jurnal EKOSAINS. Vol IV, pp. 47-61. 2014.

[9] Wunder, S. Ecotourism and Economic Incentives - an Empirical Approach. Ecological Economics. 32 (2000), pp. 465-479. 2000.

[10] Beljai, M., Muntasib, E.K.S.H.,Sulistyantara, B. Konsep Penataan Lanskap untuk Wisata Alam di Kawasan Taman Wisata Alam Sorong. Jurnal Manusia dan Lingkungan. 21 (3), pp. 356-365. 2014

[11] Karsudi, Soekmadi R, Kartodiharjo H. Strategi Pengembangan Ekowisata di Kabupaten Kepulauan Yapen Provinsi Papua. Jurnal Managemen Hutan Tropis, 16 (3), pp. 148-154. 2010.

[12] Makalew, A, D, N., Damayanti, V, D., Hadi, A, A. Rencana Penataan Lanskap. Gunung Kapur Cibadak untuk Ekowisata di Kecamatan Ciampea Kabupaten Bogor. Jurnal Ilmu Pertanian Indonesia. 13 (3), pp. 182-193. 2008

[13] Pratiwi, S. Partisipasi Masyarakat Lokal dalam Pengembangan Ekowisata: Analisis Kritis Terhadap Publikasi Terpilih. Jurnal Manajemen Hutan Tropika. XII (2), pp. 69-77. 2006.

[14] Indarjo Slamet., "Strategi dan Kebijakan Pengembangan Ekowisata Batu Katak Sebagai Daerah Peyangga Taman Nasional Gunung Leuser". Universitas Sumatera Utara, 2016.

[15] Karta NLPA dan Suarthana IKP. Strategi Komunikasi Pemasaran Ekowisata pada Destinasi Wisata Dolphin Hunting Lovina. Jurnal Manajemen Strategi Bisnis dan Kewirausahaan. 8(1), pp. 45-51. 2014.

[16] Asmawav, D. dan Verma, A.. Ecotourism for environmental conservation and community livelihoods, the case of the Bale Mountain National Park, Ethiopia. Journal of Environmental Science and Water Resources, 2(8), pp. 250-259. 2013.

[17] Flamin, A., Asnaryati.. Potensi Ekowisata dan Strategi Pengembangan Tahura Nipa-Nipa, Kota Kendari, Sulawesi Utara. Jurnal Kehutanan Wallacea. 2 (2), pp. 154-18. 2013

[18] Sudana, I, P. Strategi Pengembangan Wisata Ekologis Di Desa Belimbing, Kecamatan Pupuan, Kabupaten Tabanan. Analisa Pariwisata. 13 (1), pp. 1131. 2013

[19] Rangkuti, F.. Analisis SWOT Teknik Membedah Kasus Bisnis. Jakarta : PT Gramedia Pustaka Utama. 2000 